\title{
Enhancing the Bioconversion of Winery and Olive Mill Waste Mixtures into Lignocellulolytic Enzymes and Animal Feed by Aspergillus uvarum Using a Packed-Bed Bioreactor
}

\author{
José Manuel Salgado, ${ }^{\dagger}$ Luís Abrunhosa, $^{\dagger}$ Armando Venâncio, ${ }^{\dagger}$ José Manuel Domínguez, $^{\S}$ \\ and Isabel Belo*, ${ }^{*}$ \\ ${ }^{\dagger}$ CEB-Centre of Biological Engineering, University of Minho, Campus de Gualtar, 4710-057 Braga, Portugal \\ ${ }^{\S}$ Department of Chemical Engineering, Sciences Faculty, University of Vigo (Campus Ourense), As Lagoas s/n, 32004 Ourense, Spain
}

ABSTRACT: Wineries and olive oil industries are dominant agro-industrial activities in southern European regions. Olive pomace, exhausted grape marc, and vine shoot trimmings are lignocellulosic residues generated by these industries, which could be valued biotechnologically. In the present work these residues were used as substrate to produce cellulases and xylanases through solid-state fermentation using Aspergillus uvarum MUM 08.01. For that, two factorial designs $\left(3^{2}\right)$ were first planned to optimize substrate composition, temperature, and initial moisture level. Subsequently, the kinectics of cellulolytic enzyme production, fungal growth, and fermented solid were characterized. Finally, the process was performed in a packed-bed bioreactor. The results showed that cellulase activity improved with the optimization processes, reaching $33.56 \mathrm{U} / \mathrm{g}$, and with the packed-bed bioreactor aeration of $0.2 \mathrm{~L} / \mathrm{min}$, reaching $38.51 \mathrm{U} / \mathrm{g}$. The composition of fermented solids indicated their potential use for animal feed because cellulose, hemicellulose, lignin, and phenolic compounds were partially degraded 28.08, 10.78, 13.3, and $28.32 \%$, respectively, crude protein was increased from 8.47 to $17.08 \%$, and the mineral contents meet the requirements of main livestock.

KEYWORDS: solid-state fermentation, packed-bed bioreactor, cellulases, winery wastes, olive mill wastes, animal feed

\section{INTRODUCTION}

Enzymes are of special interest for several industrial sectors. In recent years, the value of the worldwide market for industrial enzymes has increased. In 2012 the global market for industrial enzyme reached U.S. $\$ 3.75$ billion. ${ }^{1}$ Cellulases are a complex mix of enzymes that can hydrolyze glycosidic bonds including endoglucanases, cellobiohydrolases, and $\beta$-glucosidases. These enzymes are necessary to efficiently hydrolyze cellulose. ${ }^{2}$ They have applications in the textile, food, feed, laundry, brewery, and biofuels industries. ${ }^{1}$ One of the potential applications of cellulases is the production of fuel ethanol from lignocellulosic biomass. $^{3}$ The production of cellulases is associated with xylanase production. Xylanases are glycosidases ( $O$-glycoside hydrolases, EC 3.2.1.x), which catalyze the hydrolysis of $1,4-\beta$ D-xylosidic linkages in xylan. ${ }^{4}$

Production of cellulases by solid-state fermentation (SSF) is rapidly gaining interest because this process is a cost-effective technology. SSF is a convenient technology for the production of bioproducts. SSF is performed on solid substrates in the absence (or near absence) of free water. However, substrates still need moisture to allow the growth and metabolism of microorganisms, filamentous fungi being the most suitable microorganisms to grow in these low-moisture conditions. Trichoderma reesei and Aspergillus niger produce large amounts of extracellular cellulases including endoglucanases, cellobiohydrolases (exoglucanases), and $\beta$-glucosidases. ${ }^{5}$ However, there is scant literature available on the production of cellullases by Aspergillus uvarum. In previous works, its capacity to produce cellulases $^{2}$ and lipases ${ }^{6}$ under SSF was observed. Mixtures of olive mill and winery wastes were used to produce these enzymes.
The lipase production was optimized by experimental design, and it attained a maximum activitity of $18.67 \mathrm{U} / \mathrm{g}$.

The economic value of the agro-industrial wastes could be easily increased by fungal pretreatment in SSF. ${ }^{7}$ Winery and olive mill processes generate large amounts of wastes each year. They are a serious environmental problem in the Mediterranean countries due to their high organic load and content on phenolic compounds. Both of these industrial wastes are predominantly produced during the same period of the year (from September to December) and are usually located in the same geographical area. In the winemaking process, it is estimated that from one ton of grapes are obtained $0.13 \mathrm{t}$ of marc, $0.06 \mathrm{t}$ of lees, $0.03 \mathrm{t}$ of stalks, and $1.65 \mathrm{~m}^{3}$ of wastewater. ${ }^{8}$ In addition, during grapevine pruning, a large amount of vine shoot trimmings is obtained and usually burnt in vineyards, realizing potential cancerous compounds. ${ }^{9}$ Optimization of mixed-substrate fermentation in a particular ratio is also a strategy for improvement of enzyme production. ${ }^{10,11}$

On the other hand, olive mills produce wastewaters and solid wastes in three-phase extraction systems and olive pomace in two-phase extraction systems, which may be freed into rivers, sea, and land despite being prohibited. ${ }^{12}$ Nowadays, the twophase system is the method more used. This method was introduced because it reduces the water consumption during the extraction process and thus it also reduces the olive

Received: April 28, 2015

Revised: July 10, 2015

Accepted: July 13, 2015

Published: July 13, 2015 
wastewater. It generates $800 \mathrm{~kg}$ of waste by tonne of olives. Due to their potential impact on the environment, it is important to search for new treatments or uses for these wastes.

Winery and olive mill wastes might be regarded as potential resources for SSF substrates, because they are rich in simple and complex sugars and other nutrients. ${ }^{6}$ Marc, vine shoot trimmings, and olive pomace are lignocellulosic wastes, which were not exploited in the past. Lignocellulosic wastes are attractive feedstocks for microbial enzyme production. ${ }^{13}$ Lately, significant efforts have been made to convert lignocellulosic wastes to valuable products such as biofuels, chemicals, and animal feed. ${ }^{5}$ Because their major component is cellulose, they may also be a suitable substrate to induce fungal cellulase production in SSF.

It is known that the nature of the carbon source used as substrate influences cellulase production. ${ }^{14}$ Thus, the selection of a suitable solid substrate is an important factor to take into consideration. The substrate supplies the nutrients for the fungi and acts as anchorage for them. ${ }^{15}$ However, some nutrients may be absent, so it may be necessary to supplement the substrate with more expensive commercial compounds. ${ }^{15}$ In the alternative, different residues can be mixed to provide all necessary nutrients for fungal growth. For example, Salgado et al. observed that a mixture of olive pomace, exhausted grape marc, and urea supported the production of cellulases in SSF. ${ }^{2}$ Other important parameters affecting the efficiency of SSF are moisture and temperature.

Solid-state fermentation has been used as pretreatment to improve the nutritive value of agricultural byproducts. ${ }^{16}$ The growth of fungi in these byproducts causes an increase in protein-enriched and feed additives. The agro-industrial wastes have low protein content $(2-6 \%)$, and fermented waste can improve it to $10-15 \% .{ }^{17}$ In addition, other compounds can be increased as total lipid an fatty acids. Another advantage of SSF treatment is the increase of biodegradability of agro-industrial wastes by ruminant animals and the reduced concentration of antinutricional factors such as phytic acid, polyphenols, and tannins. $^{18,19}$

In the present study, substrate composition and process parameters such as temperature and initial moisture were optimized to improve cellulase production by Aspergillus uvarum on olive mill and winery waste mixtures. Under optimal conditions, an evaluation of waste composition after SSF was carried out for its use as animal feed. In addition, the optimal conditions were applied in a packed-bed bioreactor operating at different aeration rates.

\section{MATERIALS AND METHODS}

Raw Materials and Microorganisms. Olive pomace (OP) was collected from the olive oil industry of northern Portugal in campaign $2013 / 2014$. Vine shoot trimmings (VST) were obtained from a vineyard in Galicia (northern Spain), and exhausted grape marc (EGM) and vinasses were supplied by distilleries of Galicia. OP was used directly in SSF; VST and EGM were dried at $40{ }^{\circ} \mathrm{C}$ and milled to a particle size of $<1 \mathrm{~mm}$. Characterization of the residues used is already reported. ${ }^{6} \mathrm{OP}$ and vinasses were stored at $-20{ }^{\circ} \mathrm{C}$, and dried VST and EGM were stored in vacuum-packed plastic bags.

Aspergillus uvarum MUM 08.01 was obtained from MUM culture collection (University of Minho, Braga, Portugal), where it was stored in glycerol stocks at $-80^{\circ} \mathrm{C}$. It was grown on MEA ( $2 \%$ malt extract, $2 \%$ glucose, $0.1 \%$ peptone, $2 \%$ agar). For inoculation, A. uvarum was grown on MEA slants at $25{ }^{\circ} \mathrm{C}$ for 5 days and preserved at $4{ }^{\circ} \mathrm{C}$. Fungal spores of MEA slants were resuspended in a sterile solution (0.1\% peptone, $0.01 \%$ Tween 80 ).
Enzyme Production by SSF. SSF was carried out in Erlenmeyer flasks with $15 \mathrm{~g}$ of dried solid substrate and $45 \mathrm{~mL}$ of liquid medium with vinasses, urea, and water. The fixed composition of substrate was $5 \mathrm{~g}$ of VST and $15 \mathrm{~mL}$ of vinasses. The quantities of OP, EGM, and urea were optimized by an experimental design. In the first experimental design to optimize substrate composition, the initial moisture and temperature used were $75 \%$ (wet basis) and $25{ }^{\circ} \mathrm{C}$, respectively. In the second experimental design to optimize parameters of SSF, the composition of substrate was the optimum of the first design. In all cases, the $\mathrm{pH}$ of the liquid medium was adjusted to 5.5; Erlenmeyers flasks with substrates were sterilized at $121{ }^{\circ} \mathrm{C}$ for $15 \mathrm{~min}$, cooled, and inoculated with $1 \mathrm{~mL}$ of solution $(0.1 \%$ peptone and $0.01 \%$ Tween 80$)$ with $1 \times 10^{7}$ spores $/ \mathrm{mL}$. The experiments were incubated for 6 days, and then enzymes were extracted. All experiments were carried out in duplicate, and a control without inoculum was also done. The enzyme extraction was performed at final time ( 6 days) as described in Salgado et al. ${ }^{6}$

Analysis of Enzyme Activity. Cellulase (endo-1,4- $\beta$-glucanase) activity was analyzed using an enzymatic kit Azo-CM-Cellulase S-ACMC 04/07 (Megazyme International, Ireland). One unit of enzyme activity was defined as the amount of enzyme required to release $1 \mu \mathrm{mol}$ of glucose reducing sugar equivalents from CM-cellulose in $1 \mathrm{~min}$ at $\mathrm{pH} 4.5$.

Xylanase (endo-1,4- $\beta$-xylanase) activity was analyzed using an enzymatic kit Azo wheat arabinoxylan AWX 10/2002 (Megazyme International, Ireland). One unit of enzyme activity was defined as the amount of enzyme required to release $1 \mu \mathrm{mol}$ of xylose reducing sugar equivalents from wheat arabinoxylan in $1 \mathrm{~min}$ at $\mathrm{pH} 4.5$.

Filter paper cellulase activity (FPase) was assayed by incubating the suitably diluted crude enzyme extract $(0.5 \mathrm{~mL})$ with $1.5 \mathrm{~mL}$ of citrate buffer $(50 \mathrm{mM}, \mathrm{pH} 4.8)$ containing ashless Whatman no. 40 filter paper strips $(50 \mathrm{mg}, 1 \times 6 \mathrm{~cm})$ at $50{ }^{\circ} \mathrm{C}$ for $60 \mathrm{~min}$.

$\beta$-Glucosidase activity was estimated using $\mathrm{pNPG}$ as substrate. The assay mixture containing $25 \mu \mathrm{L}$ of substrate [ $5 \mathrm{mM}$, 4-nitrophenyl $\beta$-Dglucopyranoside (pNPG)], $25 \mu \mathrm{L}$ of diluted enzyme, and $50 \mu \mathrm{L}$ of acetate buffer $(50 \mathrm{mM}, \mathrm{pH} 5.0)$ was incubated at $50{ }^{\circ} \mathrm{C}$ for $30 \mathrm{~min}$, and the $p$-nitrophenol liberated was measured at $405 \mathrm{~nm}$. One International unit (IU) of enzyme activity will be defined as the quantity of enzyme required to liberate $1 \mu \mathrm{mol}$ of glucose or p-nitrophenol per milliliter of crude filtrate per minute under standard assay conditions.

Experimental Designs. For determination of optimal substrate composition for cellulase production by SSF, a full factorial design $3^{2}$ was carried out. The two studied variables were the ones that showed a higher effect in previous studies. ${ }^{2}$ The independent variables considered and their variation ranges are shown in Table 1 . The correspondence between coded and uncoded variables was established by linear equations deduced from their respective variation limits. The response variable was cellulase activity.

This design allowed the estimation of the significance of the parameters and their interaction using Student's $t$ test. A second-order polynomial model of the form shown in eq 1 was used to fit the data:

$$
\begin{aligned}
y= & b_{0}+b_{1} x_{1}+b_{11} x_{1}^{2}+b_{2} x_{2}+b_{22} x_{2}^{2}+b_{12} x_{1} x_{2}+b_{112} x_{1}^{2} x_{2} \\
& +b_{122} x_{1} x_{2}^{2}+b_{1122} x_{1}^{2} x_{2}^{2}
\end{aligned}
$$

$y$ represents the dependent variable, $b$ denotes the regression coefficients (calculated from experimental data by multiple regression using the least-squares method), and $x$ denotes the independent variables. All experiments were carried out in duplicate and in randomized run order.

The experimental data were evaluated by response surface methodology using Statistica 5.0 software. Dependent variable was optimized using an application of commercial software (Solver, Microsoft Excel 2007, Redmond, WA, USA).

Optimization of Temperature and Initial Moisture. Temperature and initial moisture are important parameters in SSF. Using the substrate composition previously optimized, an additional experimental design $\left(3^{2}\right)$ was planned to determine optimal temperature and initial moisture conditions necessary to maximize the production of cellulases. Table 1 shows the independent variables, their ranges, and 
Table 1. Levels of Independent Variables and Dimensionless Coded Variables Definitions $\left(x_{i}\right) i^{a}$

\begin{tabular}{|c|c|c|c|c|c|}
\hline \multicolumn{6}{|c|}{ Experimental Design 1: Optimization of Substrate Composition } \\
\hline & \multirow[b]{2}{*}{ units } & \multicolumn{3}{|c|}{ levels } & \multirow[b]{2}{*}{$x_{i}$} \\
\hline & & -1 & 0 & 1 & \\
\hline \multicolumn{6}{|l|}{ independent variables } \\
\hline amount of urea $\left(x_{1}\right)$ & $\mathrm{g} / \mathrm{g}$ solid substrate & 0.01 & 0.055 & 0.1 & $(T-0.055 / 0.045)$ \\
\hline ratio EGM:OP $\left(x_{2}\right)$ & $\mathrm{g} / \mathrm{g}$ & 1 & 2 & 3 & (EGM:OP-2/1) \\
\hline fixed variables & & & value & & \\
\hline VTS & g/g solid substrate & & 0.33 & & \\
\hline vinasses & $\mathrm{mL} / \mathrm{g}$ solid substrate & & 0.5 & & \\
\hline \multicolumn{6}{|c|}{ Experimental Design 2: Optimization of SSF Parameters } \\
\hline & & \multicolumn{3}{|c|}{ levels } & \\
\hline & units & -1 & 0 & 1 & $x_{i}$ \\
\hline \multicolumn{6}{|l|}{ independent variables } \\
\hline temperature & ${ }^{\circ} \mathrm{C}$ & 25 & 30 & 35 & $(T-30 / 5)$ \\
\hline initial moisture & $\%$ & 50 & 62.5 & 75 & $(M-62.5 / 12.5)$ \\
\hline fixed variables & & & values & & \\
\hline initial $\mathrm{pH}$ & & & 5.5 & & \\
\hline inoculum & spores/mL & & $10^{7}$ & & \\
\hline
\end{tabular}

fixed variables. The effect of each independent variable to the response was fitted by the same second-order polynomial model (eq 1). Experiments were performed in duplicate, and mean values are given. The regression analysis of the experimental data obtained was performed. The fitting quality of the polynomial model equation was expressed by the coefficient of determination $R^{2}$. The optimal conditions of cellulase production were calculated using the solver function of Microsoft Excel tools. An experiment with optimal conditions was performed in triplicate to validate the model.

Finally, an experiment in triplicate with the optimal conditions obtained from the experiment design was planned to observe over time the production of enzymes, the growth of fungus by ergosterol content, degradation of solid substrate (cellulose, hemicelluloses, and lignin), and $\mathrm{C}, \mathrm{N}$, and mineral composition of solid substrate during SSF. For this, several Erlenmeyers with the same conditions were used, and each time three Erlenmeyers were retired and analyzed.

SSF in Packed-Bed Bioreactor. The conditions previously optimized were used in a packed-bed bioreactor. Experiments were carried out in a glass column $(26.3 \mathrm{~cm} \times 2.62 \mathrm{~cm})$ with a water jacket to control temperature by thermostatic bath. The aeration rate was controlled with a rotameter. In each experiment, the column was loaded with $20 \mathrm{~g}$ of optimized substrate. The substrate was charged into the column and was sterilized at $121^{\circ} \mathrm{C}$ for $15 \mathrm{~min}$. After cooling, the spore inoculum of $A$. uvarum ( $4 \mathrm{~mL}$ of solution with $10^{7}$ spores $/ \mathrm{mL}$ ) was spread over the substrate through the column entries. Moisture content and temperature were set to the optimum values obtained in previous flask experiments. Different aeration rates were studied $(0,0.2,0.4,0.6 \mathrm{~L} / \mathrm{min})$, the air was humidified and filtered through filters of $0.2 \mu \mathrm{m}$ before being sparged in the medium, and the outlet air was filtered again at the top of column. The fermentation on bioreactor was run for 7 days. After SSF, enzymes were extracted.

Analytical Methods. Nitrogen and carbon were analyzed in solids after SSF using a Thermo Finningan Flash Elemental Analyzer 1112 series (San Jose, CA, USA), and Ca, Mg, Zn, Cu, Fe, Mn, Cr, Ni, Pb, $\mathrm{Na}$, and $\mathrm{K}$ were analyzed in ashes using flame atomic absorption and atomic emission spectrometry (FFAS/FAES) using a Varian SpectrAA-220. Previously, $0.15 \mathrm{~g}$ of ashes was digested with $5 \mathrm{~mL}$ of $65 \% \mathrm{HNO}_{3}, 1 \mathrm{~mL}$ of $30 \% \mathrm{H}_{2} \mathrm{O}_{2}$, and $0.5 \mathrm{~mL}$ of $40 \% \mathrm{HF}$ in a Microwave Labstation MLS 1200 MEGA, MILESTONE (Italy). The analyses were carried out using an air/acetylene flame. FFAS was used to analyze $\mathrm{Ca}, \mathrm{Mg}$, $\mathrm{Zin}, \mathrm{Cu}, \mathrm{Fe}, \mathrm{Mn}, \mathrm{Cr}, \mathrm{Ni}$, and $\mathrm{Pb}$, and FAES was used to determine $\mathrm{Na}$ and $\mathrm{K}$. Crude protein was determined by multiplying total nitrogen content by a factor of 6.25 . Real protein increase (RPI) was calculated using the method of Durand and Chereau $^{20}$ and the equations

$$
\begin{aligned}
& \mathrm{RP}=[(\mathrm{FW} \times \mathrm{FPC})-(\mathrm{IW} \times \mathrm{IP}) / \mathrm{IW}]+\mathrm{IPC} \\
& \mathrm{RPI}=[(\mathrm{RP}-\mathrm{IP}) / \mathrm{IP}] \times 100
\end{aligned}
$$

where RP represents real protein, FW denotes final weight, FPC is final protein content, IP represents initial protein, and IW is initial weight. To determine cellulose, hemicelluloses, and Klason lignin, the substrates before and after SSF were analyzed by quantitative acid hydrolysis in a two-stage acid treatment (the first stage with $72 \mathrm{wt} \%$ sulfuric acid at $30^{\circ} \mathrm{C}$ for $1 \mathrm{~h}$ and the second stage after dilution of the medium to 4 wt $\%$ sulfuric acid at $121{ }^{\circ} \mathrm{C}$ for $1 \mathrm{~h}$ ). Natural detergent fiber was calculated as the sum of cellulose, hemicelluloses, and lignin, and acid detergent fiber was calculated as the sum of cellulose and lignin. To determine free reducing sugars and total phenols in solids after SSF, extraction with water 1:5 (w/v) was performed. Reducing sugars were determined by using the dinitrosalicylic acid method (DNS). Total phenols were determined according to the FolinCiocalteu method using caffeic acid as a standard. Weight loss was calculated after drying and weighing solids before and after SSF. The percentage of removed of cellulose, hemicellulose, and lignin was calculated by taking into account the weight loss of solids after SSF.

The growth of $A$. uvarum was estimated by ergosterol content measurements described by Salgado et al. ${ }^{6}$

\section{RESULTS AND DISCUSSION}

In previous experiments, it was demonstrated that $A$. uvarum produces cellulases and xylanases on agro-industrial wastes through SSF. ${ }^{2}$ In that work, different mixtures of winery and olive mill wastes were evaluated as substrate (OP, EGM, VST, vinasses, OMW, and commercial nutrients). An OP and EGM mixture supplemented with urea had the highest positive effect on cellulase production. These preliminary results, obtained without any optimization effort, suggested that a low-cost production process of cellulase for industrial purposes could be achieved. On the basis of this preliminary work, the composition of the mixture of OP/EGM/urea was studied and optimized to increase the yields of cellulase and xylanase.

Selection of Optimal Substrate Composition for Cellulase Production. In this study, a factorial complete design $\left(3^{2}\right)$ was used to determine the ratio of OP/EGM $(w / w)$ 
and the amount of urea ( $\mathrm{g} / \mathrm{g}$ dry substrate) that maximized the production of cellulases. The ratio of OP/EGM and urea amount were studied at three levels: $1: 1,1: 2$, and $1: 3$ and 0.01 , 0.055 , and $0.1 \mathrm{~g} / \mathrm{g}$, respectively. Figure 1 shows the surface

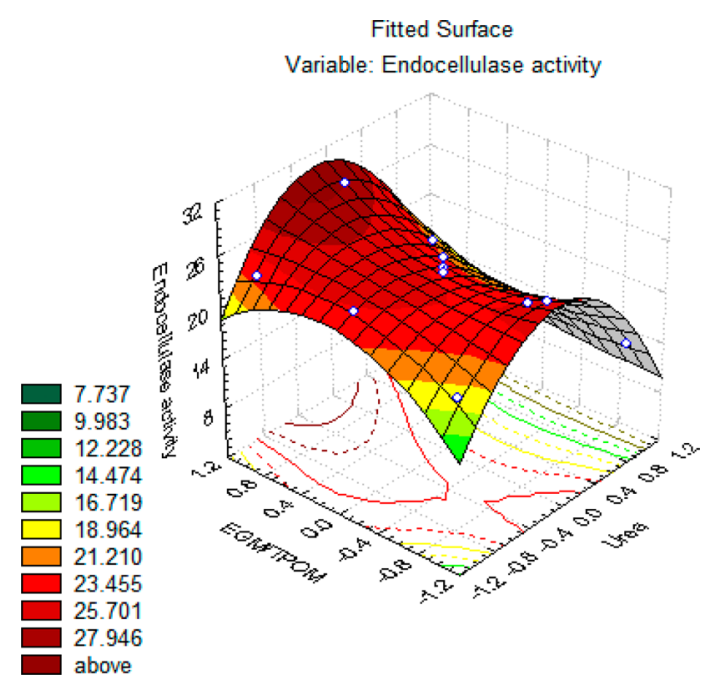

Figure 1. Response surface for cellulase production as a function of the urea (coded) and OP/EGM ratio (coded).

response for cellulase production as a function of these variables. Table 2 presents the results obtained for dependent variable cellulase activity per mass of solid substrate $(\mathrm{U} / \mathrm{g})$. According to the results of $11 \mathrm{SSF}$, the cellulase activity varied from 10.04 to $28.03 \mathrm{U} / \mathrm{g}$. Urea was the variable with higher effect on cellulase production. The urea is a source of nitrogen, which improves the production of cellulases by fungi on SSF better than other nitrogen sources. ${ }^{21}$ Assays 7-9 showed the lowest enzyme activity; these experiments were carried out with maximum concentration of urea $(0.1 \mathrm{~g}$ urea $/ \mathrm{g})$. The lower and intermediate concentrations of urea caused the highest cellulase activity. This effect was also reported by $\mathrm{Xu}$ et al., who observed that the highest concentrations of urea produced a decrease in xylanase production by $A$. niger. ${ }^{22}$

Similarly, it was observed that high OP content also decreased cellulase production. For example, with intermediate value of urea (experiments 4-6) the enzyme activity increased from 23.68 to $28.03 \mathrm{U} / \mathrm{g}$ when the amount of EGM with regard to OP increased (ratio EGM/OP from 1 to $3 \mathrm{~g} / \mathrm{g}$ ). Because OP has a higher content in phenol compounds, it may affect fungal growth and, consequently, enzyme production. Salgado et al. had already observed poor growth of fungi in OP. ${ }^{6}$ Other authors also tested the mixture of $\mathrm{OP}$ with other materials (e.g., sugar cane bagasse) to improve fungal growth. ${ }^{23}$

The statistical analysis of the results yielded an empirical coded model for cellulase activity as a function of the concentrations of urea and the ratio EGM/OP. Table 3 lists the regression coefficients and their statistical significance (based on a $t$ test, with significance level of $\alpha=0.05 \%$ ). The same table shows the coefficient of determination $R^{2}, F$ value, and significance level. $R^{2}$ is the percentage of variation of the dependent variable to be explained by the independent variables in the model. It is used to measure goodness of fit. The value of $R^{2}$ was found equal to 0.9993 , showing a good fit of data to the model. In addition, the statistical significance was checked by Fisher test ( $F$ test). This test shows an even better fit of the data to the model because values of $F_{\exp }(36.6009)>F_{\text {tab }}$
Table 2. Response Variables Obtained According to the Studied Full Factorial $3^{2}$ Design To Optimize Urea and EGM/OP Ratio ${ }^{a}$

\begin{tabular}{|c|c|c|c|c|}
\hline \multirow[b]{4}{*}{ run } & \multicolumn{4}{|c|}{ Experimental Design 1} \\
\hline & \multicolumn{2}{|c|}{ independent variables } & \multicolumn{2}{|c|}{ dependent variable } \\
\hline & \multicolumn{2}{|c|}{ real levels } & \multirow{2}{*}{$\frac{\text { observed }}{Y_{1}(\mathrm{U} / \mathrm{g})}$} & \multirow{2}{*}{$\frac{\text { predicted }}{Y_{1}(\mathrm{U} / \mathrm{g})}$} \\
\hline & $X_{1}(\mathrm{~g}$ urea $/ \mathrm{g})$ & $X_{2}$ (EGM/OP ratio) & & \\
\hline 1 & 0.01 & 1 & $17.98 \pm 0.52$ & 17.98 \\
\hline 2 & 0.01 & 2 & $23.26 \pm 0.31$ & 23.26 \\
\hline 3 & 0.01 & 3 & $21.87 \pm 0.24$ & 21.87 \\
\hline 4 & 0.055 & 1 & $23.68 \pm 0.18$ & 23.68 \\
\hline 5 & 0.055 & 2 & $22.14 \pm 0.33$ & 22.35 \\
\hline 6 & 0.055 & 3 & $28.03 \pm 0.27$ & 28.03 \\
\hline 7 & 0.1 & 1 & $10.44 \pm 0.11$ & 10.44 \\
\hline 8 & 0.1 & 2 & $10.04 \pm 0.07$ & 10.04 \\
\hline 9 & 0.1 & 3 & $13.28 \pm 0.05$ & 13.28 \\
\hline 10 & 0.055 & 2 & $21.39 \pm 0.13$ & 22.35 \\
\hline 11 & 0.055 & 2 & $23.53 \pm 0.41$ & 22.35 \\
\hline \multicolumn{5}{|c|}{ Experimental Design 2} \\
\hline run & $X_{1}\left({ }^{\circ} \mathrm{C}\right)$ & $X_{2}(\%)$ & $Y_{1}(\mathrm{U} / \mathrm{g})$ & $Y_{1}(\mathrm{U} / \mathrm{g})$ \\
\hline 1 & 25 & 50 & $19.80 \pm 0.32$ & 19.80 \\
\hline 2 & 25 & 62.5 & $24.12 \pm 0.87$ & 24.12 \\
\hline 3 & 25 & 75 & $29.97 \pm 0.65$ & 29.75 \\
\hline 4 & 30 & 50 & $26.00 \pm 0.34$ & 26.00 \\
\hline 5 & 30 & 62.5 & $28.39 \pm 0.45$ & 28.42 \\
\hline 6 & 30 & 75 & $32.53 \pm 0.65$ & 32.53 \\
\hline 7 & 35 & 50 & $18.24 \pm 0.23$ & 18.02 \\
\hline 8 & 35 & 62.5 & $20.07 \pm 0.43$ & 20.07 \\
\hline 9 & 35 & 75 & $24.60 \pm 0.31$ & 25.38 \\
\hline 10 & 30 & 62.5 & $28.17 \pm 0.62$ & 28.42 \\
\hline 11 & 30 & 62.5 & $28.71 \pm 0.18$ & 28.42 \\
\hline
\end{tabular}

${ }^{a} X_{1}$, urea (uncoded); $X_{2}$, EGM/OP ratio; $Y_{1}$, cellulase activity; g, grams of dry substrate.

(19.371) at 95\% confidence level were obtained. In this case, the higher value of $F_{\exp }$ proves that the variations in the data can be explained by the influence of the factors and that the estimated factor effects are real. The optimal conditions calculated by Solver tool were $0.045 \mathrm{~g}$ urea/g and $3 \mathrm{~g}$ EGM/g OP. Moreover, the confirmatory experiments carried out using the predicted conditions showed similar activities between experimental $(27.77 \pm 0.58 \mathrm{U} / \mathrm{g})$ and predicted value $(28.47 \mathrm{U} / \mathrm{g})$.

Optimization of SSF Parameters. The moisture level and temperature were optimized by full factorial design $\left(3^{2}\right)$. The experimental conditions, the results of the experimental designs, and the model prediction are summarized in Table 2 . The moisture level of solid substrate affects the microorganism physiology as cellular mechanisms, radial growth, and orientation of fungus. ${ }^{24}$ Therefore, it is advisible to determine the optimum moisture level for enzyme production. ${ }^{25}$ The enzyme production was evaluated at moisture contents that ranged from 50 to $75 \%$. The moisture of solid substrate, the composition of which was previously optimized, was adjusted with vinasses and urea solution. The effect of temperature was evaluated by incubating the fermentations at $25-35^{\circ} \mathrm{C}$. As can be seen from regression coefficients in Table 3, temperature had a significant effect on cellulase production. Intermediate temperature around $30^{\circ} \mathrm{C}$ led to the maximum enzyme activity. This optimal temperature was also observed by other authors in the production of cellulases by SSF with Cladosporium cladosporioides grown on sugar beet peel $^{21}$ and with Aspergillus japonicus grown on wheat bran. ${ }^{26}$ 
Table 3. Regression Coefficients and Correlation and Statistical Significance Parameters of Experimental Designs 1 and 2

\begin{tabular}{|c|c|c|c|c|}
\hline & regression coefficient ${ }^{a}$ & standard error & $t$ & $P$ \\
\hline \multicolumn{5}{|c|}{ Experimental Design 1} \\
\hline$b_{0}$ & $22.35 * * *$ & 0.6269 & 35.6566 & 0.0008 \\
\hline$b_{1}$ & $-6.61^{* *}$ & 0.7678 & -8.6090 & 0.0132 \\
\hline$b_{11}$ & $-5.70^{* *}$ & 0.9912 & -5.7538 & 0.0289 \\
\hline$b_{2}$ & 2.18 & 0.7678 & 2.8328 & 0.1053 \\
\hline$b_{22}$ & $3.50 *$ & 0.9912 & 3.5327 & 0.0716 \\
\hline$b_{12}$ & -0.26 & 0.5429 & -0.4835 & 0.6765 \\
\hline$b_{112}$ & 2.58 & 0.9404 & 2.7410 & 0.1113 \\
\hline$b_{122}$ & -0.49 & 0.9404 & -0.5237 & 0.6527 \\
\hline$b_{1122}$ & -4.26 & 1.3663 & -3.1173 & 0.0893 \\
\hline \multicolumn{5}{|c|}{ Experimental Design 2} \\
\hline$b_{0}$ & $22.35 * * *$ & 0.6269 & 35.6566 & 0.0008 \\
\hline$b_{1}$ & $-6.61 * *$ & 0.7678 & -8.6090 & 0.0132 \\
\hline$b_{11}$ & $-5.70 * *$ & 0.9912 & -5.7538 & 0.0289 \\
\hline$b_{2}$ & 2.18 & 0.7678 & 2.8328 & 0.1053 \\
\hline$b_{22}$ & $3.50 *$ & 0.9912 & 3.5327 & 0.0716 \\
\hline$b_{12}$ & -0.26 & 0.5429 & -0.4835 & 0.6765 \\
\hline$b_{112}$ & 2.58 & 0.9404 & 2.7410 & 0.1113 \\
\hline$b_{122}$ & -0.49 & 0.9404 & -0.5237 & 0.6527 \\
\hline$b_{1122}$ & $-4.26^{a}$ & 1.3663 & -3.1173 & 0.0893 \\
\hline \multicolumn{5}{|c|}{ Correlation and Statistical Significance Parameters ${ }^{b}$} \\
\hline & $R^{2}$ & $r^{2}$ adjusted & $F_{\text {exp }}$ & $P$ \\
\hline$y_{1}$ & 0.9966 & 0.9661 & 36.6009 & 0.0268 \\
\hline$y_{2}$ & 0.9996 & 0.9965 & 356.8946 & 0.0028 \\
\hline
\end{tabular}

$a_{*}$, significant coefficient at $90 \%$; $* *$, significant coefficient at $95 \%$; $* * *$, significant coefficient at $99 \%$. ${ }^{b} P$, probability; $R$, multiple correlation coefficient; $R^{2}$, determination coefficient, $\alpha=0.05 \%$; $y_{1}$, cellulase activity in experimental design $1 ; y_{2}$, cellulase activity in experimental design 2 .

The moisture level is well recognized as one of the most critical parameters in SSF. The moisture requirements vary with the organism, the operational conditions, and the solid substrate, affecting both the microbial growth and the production and secretion of enzymes. ${ }^{27}$ A positive effect of the moisture level was observed, with the maximum cellulase activity being achieved at $75 \%$ moisture. Higher moisture levels are known to promote a better availability and diffusion of nutrients and to increase the stability of enzymes and may explain the increase of cellulase activity at $75 \% .{ }^{28}$ The optimal range for cellulase production can be seen in the response surface (Figure 2).

The statistical parameters ( $F$ value, $R^{2}$, and $p$ ) of Table 3 showed a good adjustment of data to the model. On the basis of the $F$ test, the independent variables of the model explain the variability of enzyme activities, given the higher value for calculated $F$ value. The $R^{2}$ was close to 1 , confirming the good fit of the model. The optimal conditions calculated with the Solver tool that led to maximum activity were $29^{\circ} \mathrm{C}$ and $75 \%$, respectively, for the temperature and moisture parameters. The validation of the model was performed in these conditions. The achieved cellulase activity was $33.56 \pm 1.32 \mathrm{U} / \mathrm{g}$, close to the maximum value predicted by the model, which was $32.87 \mathrm{U} / \mathrm{g}$. In these experiments other lignocellulolytic enzymes were determined as xylanases $(10.36 \pm 0.54 \mathrm{U} / \mathrm{g})$, FPase $(4.65 \pm 0.13 \mathrm{U} / \mathrm{g})$, and $\beta$-glucosidase $(1.18 \pm 0.09 \mathrm{U} / \mathrm{g})$.

Evolution of Cellulase and Xylanase Production during SSF under Optimal Conditions. The time course of cellulase (endocellulase, FPase, and $\beta$-glucosidase) and

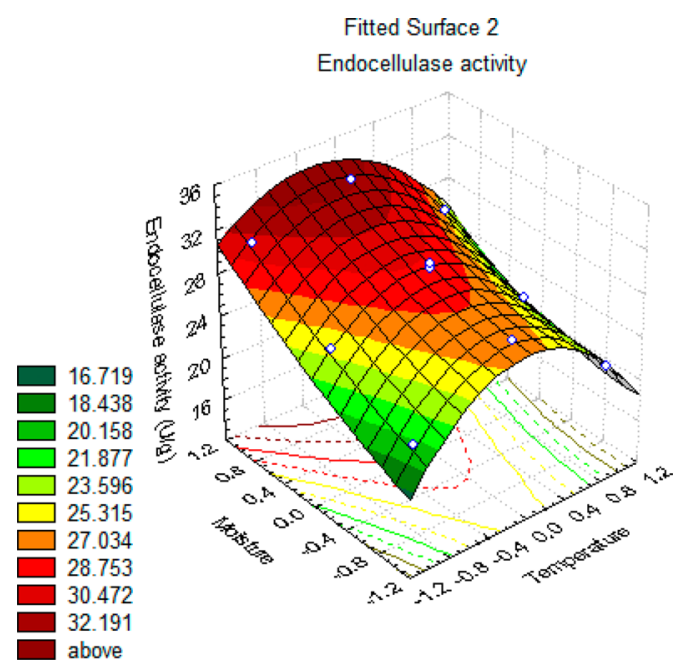

Figure 2. Response surface for cellulase production as a function of the temperature (coded) and moisture level (coded).

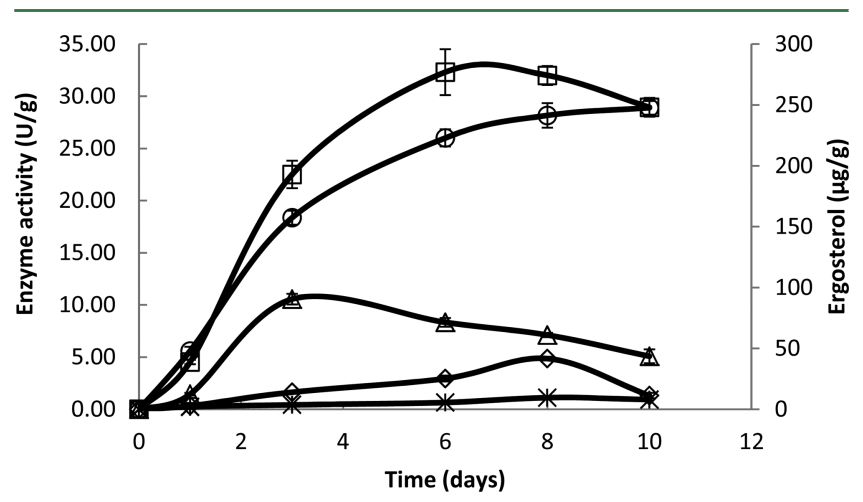

Figure 3. Time course of endocellulase $(\square)$, endoxylanase $(\triangle)$, $\beta$-glucosidase $(*)$, Fpase $(\diamond)$, and ergosterol content $(O)$ during SSF under optimal conditions.

xylanase (endoxylanase) activities and ergosterol content during several days are shown in Figure 3. The highest cellulase and xylanase activities $(32.31 \pm 2.20$ and $10.56 \pm 0.42$, respectively) were achieved after 6 days of fermentation; however, maximum FPase and $\beta$-glucosidase activities (4.86 \pm 018 and $1.12 \pm 0.09$, respectively) were observed only after 8 days. Ergosterol content is related to fungal growth, because it is a component of fungal cell membranes. In these experiments, its determination over time showed a continuous increase until the eighth day, with a maximum growth rate between the first and third days of incubation.

Changes in Composition of Solid after SSF. At the start and at each time of SSF, the solids (optimal mixture of olive pomace and EGM) were analyzed to follow the change of its nutritional composition. It was observed that fermented solids have potential to be used as animal feed. Table 4 shows the cellulose, hemicellulose, lignin, natural detergent fiber (NDF), acid detergent fiber $(\mathrm{ADF})$, reducing sugars, phenolic compounds, and crude protein composition of fermented solids, as their weight and moisture contents. NDF and ADF are correlated with digestibility of plant biomass; NDF is the sum of cellulose, hemicellulose, and lignin, and $\mathrm{ADF}$ is the sum of cellulose and lignin. Figure 4 displays the maximal reduction of cellulose, hemicellulose, lignin, reducing sugars, and phenolic compounds, the increase of protein and RPI, and the fermentation time needed to reach them. As can be observed, the A. uvarum 
ஓ

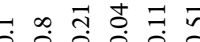

$+1+1+1+1+1$

$\approx 0 \infty \approx \pi$

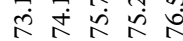

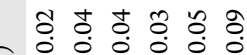

300 $+1+1+1+1+1+$

३ \& $\sigma$ के के

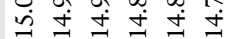

灵

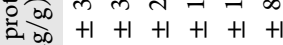

च트

है

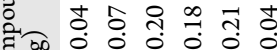

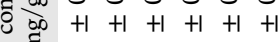

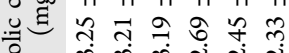

है

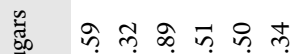

चि का 00000

bo bo $+1+1+1+1+1+$

:

च त्र

s

응후 $=0$

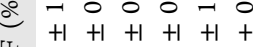

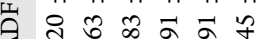

लं हुं

๙

$2+1+1+1+1$

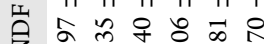

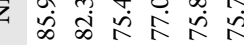

๙

$+1+1+1+1+$

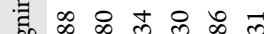

$=$ 字

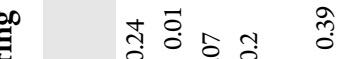

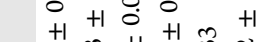

(0)

i $-i+1$

o

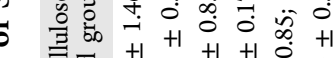

ह

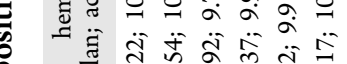

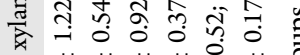

$+1+1+1+1+1$

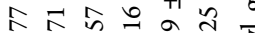

ป

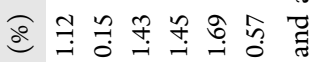

$\approx+1+1+1+1+1+1$ 年

כ

चै तु

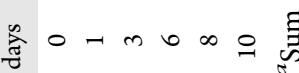

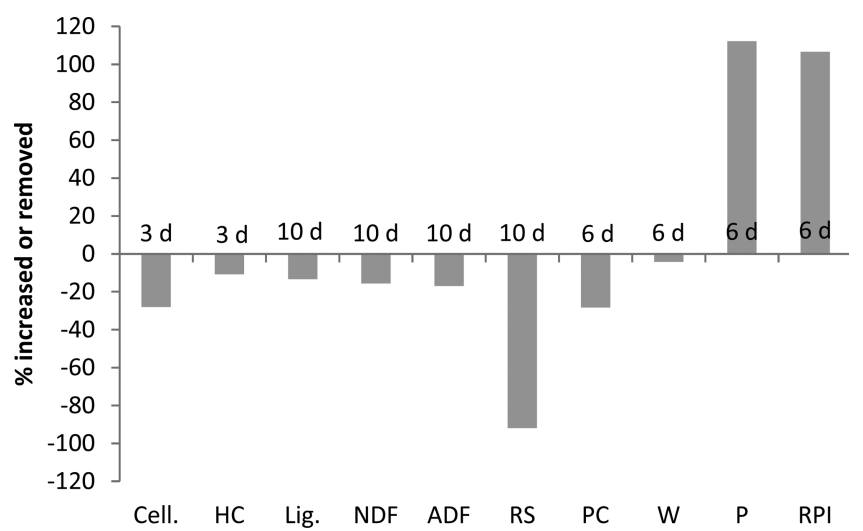

Figure 4. Maximum increase or reduction of minerals of solid after SSF under optimal conditions and the time taken to reach them.

SSF reduced cellulose, hemicellulose, and lignin contents of substrate by $28.08,10.78$, and $13.3 \%$, respectively. The weight loss was taken into account to calculate the percent removed of these compounds. The production of lignocellulytic enzymes, shown above, allowed the degradation of cellulose, hemicellulose, and lignin. These reductions improve solids digestibility and the accessibility of holocellulose by animals. ${ }^{29}$ Other Aspergilli strains have been used to degrade these compounds. For example, Aspergillus niger reduced the cellulose content of palm kernel cake to $36.02 \%$ and hemicellulose to $48.66 \%,{ }^{30}$ as well as the cellulose and hemicellulose contents on wheat straw from 46.58 and $30.17 \%$ to from 46.57 and $24.60 \%$, respectively. ${ }^{31}$ Another work, which studied the cocultivation of three different fungi (Aspergillus oryzae, Trichoderma reesei, and Phanerochaete chrysosporium) on soybean- and corn-processing coproducts also demonstrated decreases in cellulose, hemicellulose, and lignin of $1.6,13.4$, and $0.4 \%$, respectively. ${ }^{32}$

On the other hand, the increase of crude protein content after SSF is also an important parameter to take into consideration. SSF has been used to improve the nutritional value of agro-food byproducts mainly because the fungus growth increases the protein content. In this study, the percentage of protein increased from 8.47 to $17.98 \%$ after 6 days of fermentation. The RPI was $106.68 \%$, which means that A. uvarum SSF allowed the optimum value of crude protein for animal feed to be achieved. For example, basal broiler chicken diets should include a crude protein level of $18.46 \%$ during the first $7-8$ weeks and $15.95 \%$ for the subsequent $9-14$ weeks. ${ }^{33}$ Other Aspergilli strains were used to improve the nutritional value of lignocellulosic materials. For example, A. niger was used to ferment white straw, increasing the protein content from 5.01 to $7.54 \%{ }^{31}$ Illuyemi et al. also observed increasing crude protein on palm kernel cake fermented with A. niger from 18.28 to $30.18 \%$, which corresponds to a real protein increase of $37.53 \%$ after 7 days of fermentation. ${ }^{30}$

Phenolic compounds were also degraded during SSF; A. uvarum already demonstrated that it can reduce the phenolic compounds of olive mill wastewater in submerged fermentation. In this study, the fungus reduced $28.32 \%$ of phenolic compounds after 10 days of fermentation. This effect was also observed in SSF of olive cake by Fomes fomentarious ${ }^{34}$ and SSF of viticulture byproducts by Plerotus species. ${ }^{35}$ The phenolic compounds induce a negative response when they are consumed by livestock; they negatively affect animal's feed intake, feed digestibility, and production efficiency. ${ }^{36}$

Table 5 shows the mineral composition of substrate (mixture of olive pomace and EGM). Its major mineral constituents are 


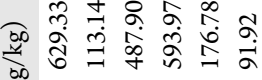

$\Xi+1+1+1+1+1+1$

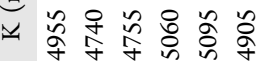

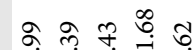

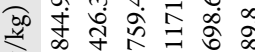

E $+1+1+1+1+1+1$

そூ

苍

कo

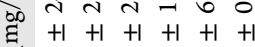

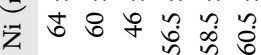

क人

+ $+1+1+1+1$

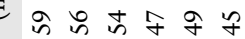

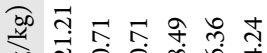

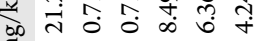

先 $+1+1+1+1$

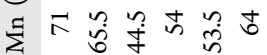

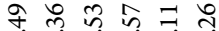

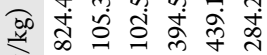

ह $+1+1+1+1+1$

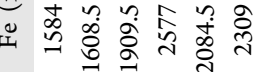

कृ

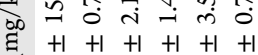

उ

孛号学

ת

छิ

कி $\infty \infty \infty \infty$

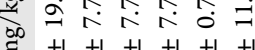

क

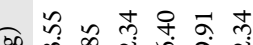

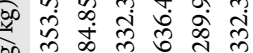

E $+1+1+1+1+1+1$

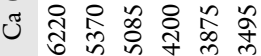

$z \vec{\infty} \vec{\infty} \infty \infty \hat{\alpha} \infty$

u

$\infty \bar{n} \quad \forall \vec{m} \infty$

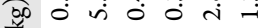

$5+1+1+1+1+1+1$

7 藏

అ

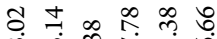

品

$+1+1+1+1+1$

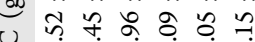

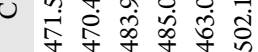

है

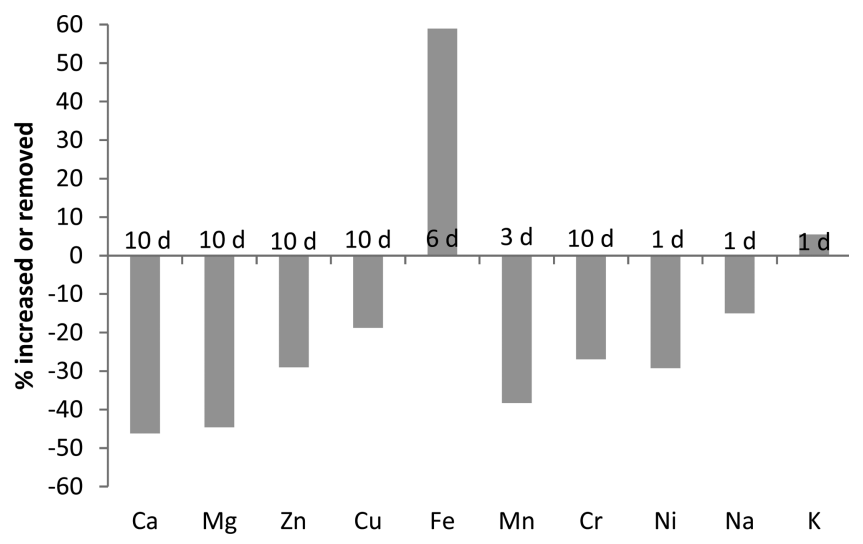

Figure 5. Maximum increase or reduction of compounds of solid after SSF under optimal conditions and the time it took to reach them.

$\mathrm{Na}, \mathrm{K}, \mathrm{Ca}, \mathrm{Fe}$, and $\mathrm{Mg}$. All minerals were reduced during SSF, except $\mathrm{Fe}$ and $\mathrm{K}$ (Figure 5): Fe increased to $58.95 \%(2.57 \mathrm{~g} / \mathrm{kg})$ after 6 days of fermentation and decreased to $2.31 \mathrm{~g} / \mathrm{kg}$ after 10 days. The increase of iron was observed by Wang et al. in a SSF of wheat bran supplemented by porcine blood using A. oryzae. ${ }^{37}$ The same effect was identified by Joshi et al. in SSF of apple pomace by yeasts. ${ }^{38}$ The minerals that were more consumed were $\mathrm{Ca}, \mathrm{Mg}$, and $\mathrm{Mn}(46.5,44.58$, and $38.27 \%$ of total, respectively). Some minerals can be essential for the diet of livestock; for example, chromium may enhance growth rate and egg quality in meat and egg type chickens, respectively. ${ }^{39}$ Table 6 shows the mineral requirements of the main livestock and the minerals composition of fermented substrate after 10 days. As can be observed, the fermented solids can fulfill all mineral requirements of poultry, swine, beef cattle, fish, and crustaceans.

Application of Optimal Conditions in Packed-Bed Bioreactor. After the optimization of substrate and parameters of SSF, the production of cellulases was studied in a packed-bed bioreactor. A glass column bioreactor was designed to carry out these experiments with air control to supply oxygen to the fungus and maintain the humidity of the substrate, because the air can be humidified before its entrance into the bioreactor. The influence of different air flows was evaluated using optimum medium and optimal SSF parameters. Three air flow rates were studied $(0.2,0.4$, and $0.6 \mathrm{~L} / \mathrm{min})$. Figure 6 shows the cellulase and xylanase activities obtained in these conditions and without air supply. As can be observed, the maximum cellulase activity $(38.51 \pm 0.53 \mathrm{U} / \mathrm{g})$ was achieved at $0.2 \mathrm{~L} / \mathrm{min}$, which is approximately $18 \%$ higher than the activity obtained without air supply. In addition, it is $15 \%$ higher than the activity obtained in experiments conducted in Erlenmeyer flasks. Hence, a positive effect of aeration was observed, but air flow rates $>0.2 \mathrm{~L} / \mathrm{min}$ caused a decrease in cellulase activity. On the contrary, the xylanase activities were similar at 0.2 and $0.4 \mathrm{~L} / \mathrm{min}$ and without air, being slightly higher at $0.2 \mathrm{~L} / \mathrm{min}$. This positive effect of aeration on cellulase production can be due to an increase in the porosity of the solid bed, allowing better oxygen transfer in the system. ${ }^{45}$ In addition, the advantageous effect of forced aeration may be related to the capacity of the airstream to remove heat, avoiding temperature levels that would be deleterious to the microorganism and enzymes. ${ }^{46}$

This study improved clearly the production of cellulases and xylanases by $A$. uvarum through SSF after having optimized the substrate composition and SSF parameters. Optimal conditions for substrate composition were $0.045 \mathrm{~g}$ urea/g and $3 \mathrm{~g} \mathrm{EGM} / \mathrm{g}$ OP and for SSF parameters were $29{ }^{\circ} \mathrm{C}$ and $75 \%$, and the 
Table 6. Minerals Supplied by Fermented Solids and Dietary Mineral Requirements of Animals

\begin{tabular}{|c|c|c|c|c|c|}
\hline mineral & substrate after SSF (mg/kg) & poultry $(\mathrm{mg} / \mathrm{kg})$ & swine $(\mathrm{mg} / \mathrm{kg})$ & beef cattle $(\mathrm{mg} / \mathrm{kg})$ & fish and crustacean $(\mathrm{mg} / \mathrm{kg})$ \\
\hline $\mathrm{Ca}$ & 3495.0 & $8000-10000^{a}$ & & $1800-10400^{b}$ & $1700-15000^{c}$ \\
\hline $\mathrm{Mg}$ & 410.0 & $600^{a}$ & & $400-1000^{b}$ & $400-1000^{c}$ \\
\hline $\mathrm{Zn}$ & 20.0 & $50-60^{d}$ & $70-150^{d}$ & $17.2-30^{b}$ & $17.2-30^{c}$ \\
\hline $\mathrm{Cu}$ & 80.5 & $44^{a}$ & $20-165^{d}$ & $4.4^{b}$ & $4.4^{c}$ \\
\hline $\mathrm{Fe}$ & 2309.0 & $1335^{a}$ & $100^{e}$ & $4^{b}$ & $4^{c}$ \\
\hline $\mathrm{Mn}$ & 64.0 & $60-70^{b}$ & $30-40^{d}$ & $0.9-9.9^{b}$ & $0.9-9.9^{c}$ \\
\hline $\mathrm{Cr}$ & 45.0 & $11.2^{a}$ & & & \\
\hline $\mathrm{Ni}$ & 60.5 & & & & \\
\hline $\mathrm{Na}$ & 9548.5 & $20000^{a}$ & & & $600^{c}$ \\
\hline $\mathrm{K}$ & 4905.0 & $3000^{a}$ & & & $6000-8000^{c}$ \\
\hline
\end{tabular}

Packed-bed bioreactor

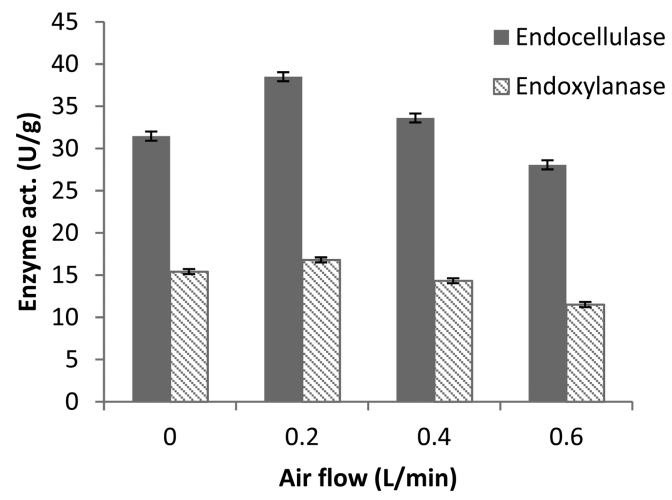

Figure 6. Cellulase and xylanase production by SSF in packed-bed bioreactor under optimal conditions at different aeration rates.

maximum activity achieved was $33.56 \mathrm{U} / \mathrm{g}$. In addition, the implementation of the process in a packed-bed bioreactor enhanced the production of cellulases by $15 \%$. On the other hand, the nutritional composition of solids after SSF showed that they have potential to be used as animal feed. However, further studies are required to ascertain their digestibility. The analysis of fermented solid at different times allowed the determination that time is optimal for degradation or increase of each component with interest for animal feed.

\section{AUTHOR INFORMATION}

\section{Corresponding Author}

*(I.B.) Phone: (+351) 253604 413. Fax: (+351) 253604429.

E-mail: ibelo@deb.uminho.pt.

\section{Funding}

J.M.S. was supported by Grant SFRH/BPD/84440/2012 from Fundação para a Ciência e Tecnologia (FCT), Portugal. L.A. was supported by Grant Incentivo/EQB/LA0023/2014 from O Novo Norte (ON.2). We thank FCT Strategic Project PEstOE/EQB/LA0023/2013 and the Project "BioInd - Biotechnology and Bioengineering for improved Industrial and Agro-Food processes, Rer. NORTE-07-0124-FEDER-000028” co-funded by the Programa Operacional Regional do Norte (ON.2), QREN, FEDER

\section{Notes}

The authors declare no competing financial interest.

\section{REFERENCES}

(1) Ferreira, N. L.; Margeot, A.; Blanquet, S.; Berrin, J. Use of cellulases from Trichoderma reesei in the twenty-first century part I: current industrial uses and future applications in the production of second ethanol generation. In Biotechnology and Biology of Trichoderma; Elsevier: Amsterdam, The Netherlands, 2014; pp 245258.

(2) Salgado, J. M.; Abrunhosa, L.; Venâncio, A.; Domínguez, J. M.; Belo, I. Screening of winery and olive mill wastes for lignocellulolytic enzyme production from Aspergillus species by solid-state fermentation. Biomass Convers. Biorefin. 2014, 4, 201-209.

(3) Narra, M.; Dixit, G.; Divecha, J.; Madamwar, D.; Shah, A. R. Production of cellulases by solid state fermentation with Aspergillus terreus and enzymatic hydrolysis of mild alkali-treated rice straw. Bioresour. Technol. 2012, 121, 355-361.

(4) Collins, T.; Gerday, C.; Feller, G. Xylanases, xylanase families and extremophilic xylanases. FEMS Microbiol. Rev. 2005, 29 (1), 3-23.

(5) Dashtban, M.; Schraft, H.; Qin, W. Fungal bioconversion of lignocellulosic residues; opportunities \& perspectives. Int. J. Biol. Sci. 2009, 5 (6), 578-595.

(6) Salgado, J. M.; Abrunhosa, L.; Venâncio, A.; Domínguez, J. M.; Belo, I. Integrated use of residues from olive mill and winery for lipase production by solid state fermentation with Aspergillus sp. Appl. Biochem. Biotechnol. 2014, 172 (4), 1832-1845.

(7) Dulf, F. V.; Vodnar, D. C.; Dulf, E.; Toșa, M. I. Total phenolic contents, antioxidant activities, and lipid fractions from berry pomaces obtained by solid-state fermentation of two Sambucus species with aspergillus niger. J. Agric. Food Chem. 2015, 63 (13), 3489-3500.

(8) Oliveira, M.; Duarte, E. Integrated approach to winery waste: waste generation and data consolidation. Front. Environ. Sci. Eng. 2014, April, 1-9.

(9) Devesa-Rey, R.; Vecino, X.; Varela-Alende, J. L.; Barral, M. T.; Cruz, J. M.; Moldes, A. B. Valorization of winery waste vs. the costs of not recycling. Waste Manage. 2011, 31 (11), 2327-35.

(10) Das, A.; Paul, T.; Halder, S. K.; Jana, A.; Maity, C.; Das Mohapatra, P. K.; Pati, B. R.; Mondal, K. C. Production of cellulolytic enzymes by Aspergillus fumigatus ABK9 in wheat bran-rice straw mixed substrate and use of cocktail enzymes for deinking of waste office paper pulp. Bioresour. Technol. 2013, 128, 290-296.

(11) Sandhu, S. K.; Oberoi, H. S.; Babbar, N.; Miglani, K.; Chadha, B. S.; Nanda, D. K. Two-stage statistical medium optimization for augmented cellulase production via solid-state fermentation by newly isolated Aspergillus niger $\mathrm{HN}-1$ and application of crude cellulase consortium in hydrolysis of rice straw. J. Agric. Food Chem. 2013, 61 (51), 12653-12661.

(12) Coz, A.; Villegas, M.; Andrés, A.; Viguri, J. R.; Mantzavinos, D.; Xekoukoulotakis, N. P. Management scenarios for olive oil mill waste based on characterization and leaching tests. J. Chem. Technol. Biotechnol. 2011, 86 (12), 1542-1547.

(13) Cheirsilp, B.; Kitcha, S. Solid state fermentation by cellulolytic oleaginous fungi for direct conversion of lignocellulosic biomass into lipids: fed-batch and repeated-batch fermentations. Ind. Crops Prod. 2015, 66, 73-80.

(14) Jecu, L. Solid state fermentation of agricultural wastes for endoglucanase production. Ind. Crops Prod. 2000, 11 (1), 1-5. 
(15) Pandey, A.; Selvakumar, P.; Soccol, C. R.; Nigam, P. Solid state fermentation for the production of industrial enzymes. Curr. Sci. 1999, 77, 149-162.

(16) Ajila, C. M.; Brar, S. K.; Verma, M.; Tyagi, R. D.; Godbout, S.; Valéro, J. R. Bio-processing of agro-byproducts to animal feed. Crit. Rev. Biotechnol. 2012, 32, 1-19.

(17) Shojaosadati, S. A.; Faraidouni, R.; Madadi-Nouei, A.; Mohamadpour, I. Protein enrichment of lignocellulosic substrates by solid state fermentation using Neurospora sitophila. Resour. Conserv. Recyc. 1999, 27, 73-87.

(18) Mandebvu, P.; West, J. W.; Froetschel, M. A.; Hatfield, R. D.; Gates, R. N.; Hill, G. M. Effects of enzyme and microbial treatment of bermudagrass forages before ensiling on cell wall composition, end products of silage fermentation and in situ digestion kinetics. Anim. Feed Sci. Technol. 1999, 77, 317-329.

(19) Elyas, S. H. A.; El Tinay, A. H.; Yousif, N. E.; Elsheikh, E. A. E. Effect of natural fermentation on nutritive value and in vitro protein digestibility of pearl millet. Food Chem. 2002, 78, 75-79.

(20) Durand, A.; Chereau, D. A new pilot reactor for solid state fermentation: application to the protein enrichment of sugar beet pulp. Biotechnol. Bioeng. 1988, 31, 476-486.

(21) Mushimiyimana, I.; Tallapragada, P. Optimization of process parameters for biosynthesis of cellulase by Cladosporium cladosporioides using agro wastes. Int. J. Pharma Bio Sci. 2013, 4 (4), 1129-1138.

(22) Xu, Y. X.; Li, Y. L.; Xu, S. C.; Liu, Y.; Wang, X.; Tang, J. W. Improvement of xylanase production by Aspergillus niger XY-1 using response surface methodology for optimizing the medium composition. J. Zhejiang Univ., Sci., B 2008, 9 (7), 558-566.

(23) Aloui, F.; Abid, N.; Roussos, S.; Sayadi, S. Decolorization of semisolid olive residues of "alperujo" during the solid state fermentation by Phanerochaete chrysosporium, Trametes versicolor, Pycnoporus cinnabarinus and Aspergillus niger. Biochem. Eng. J. 2007, 35 (2), 120-125.

(24) Gervais, P.; Molin, P. The role of water in solid-state fermentation. Biochem. Eng. J. 2003, 13 (2-3), 85-101.

(25) Maurya, D. P.; Singh, D.; Pratap, D.; Maurya, J. P. Optimization of solid state fermentation conditions for the production of cellulase by Trichoderma reesei. J. Environ. Biol. 2012, 33, 5-8.

(26) Facchini, F. D. A.; Vici, A. C.; Reis, V. R. A.; Jorge, J. A.; Terenzi, H. F.; Reis, R. A.; Polizeli, M. L. Production of fibrolytic enzymes by Aspergillus japonicus $\mathrm{C} 03$ using agro-industrial residues with potential application as additives in animal feed. Bioprocess Biosyst. Eng. 2011, 34 (3), 347-355.

(27) Zimbardi, A. L. R. L.; Sehn, C.; Meleiro, L. P.; Souza, F. H. M.; Masui, D. C.; Nozawa, M. S. F.; Guimarães, L. H. S.; Jorge, J. A.; Furriel, R. P. M. Optimization of $\beta$-glucosidase, $\beta$-xylosidase and xylanase production by Colletotrichum graminicola under solid-state fermentation and application in raw sugarcane trash saccharification. Int. J. Mol. Sci. 2013, 14 (2), 2875-2902.

(28) Dogaris, I.; Vakontios, G.; Kalogeris, E.; Mamma, D.; Kekos, D. Induction of cellulases and hemicellulases from Neurospora crassa under solid-state cultivation for bioconversion of sorghum bagasse into ethanol. Ind. Crops Prod. 2009, 9, 404-411.

(29) Sharma, R. K.; Arora, D. S. Changes in biochemical constituents of paddy straw during degradation by white rot fungi and its impact on in vitro digestibility. J. Appl. Microbiol. 2010, 109 (2), 679-686.

(30) Iluyemi, F. B.; Hanafi, M. M. Fungal solid state culture of palm kernel cake. Bioresour. Technol. 2006, 97, 477-482.

(31) Jahromi, M. F.; Liang, J. B.; Rosfarizan, M.; Goh, Y. M.; Shokryazdan, P.; Ho, Y. W. Effects of Aspergillus niger (K8) on nutritive value of rice straw. J. Biotechnol. 2010, 9 (42), 7043-7047.

(32) Lio, J.; Wang, T. Solid-state fermentation of soybean and corn processing coproducts for potential feed improvement. J. Agric. Food Chem. 2012, 60 (31), 7702-7709.

(33) Li, F.; Li, F.; Zhao, T.; Mao, G.; Zhou, Y.; Zheng, D.; Takase, M.; Feng, W.; Wu, X.; Yang, L. Solid-state fermentation of industrial solid wastes from the fruits of milk thistle Silybum marianum for feed quality improvement. Appl. Microbiol. Biotechnol. 2013, 97 (15), 6725-6737.
(34) Neifar, M.; Jaouani, A.; Ayari, A.; Abid, O.; Salem, H. B.; Boudabous, A.; Najar, T.; Ghorbel, R. E. Improving the nutritive value of olive cake by solid state cultivation of the medicinal mushroom Fomes fomentarius. Chemosphere 2013, 91 (1), 110-114.

(35) Sánchez, A.; Ysunza, F.; Beltran-García, M. J.; Esqueda, M. Biodegradation of viticulture wastes by pleurotus: a source of microbial and human food and its potential use in animal feeding. J. Agric. Food Chem. 2002, 50 (9), 2537-2542.

(36) Van Soest, P. J. Nutritional Ecology of the Ruminants, 2nd ed.; Cornell University Press: Ithaca, NY, USA, 1994.

(37) Wang, J. Z.; Zhang, M.; Ren, F. Z.; Han, B. Z.; Wang, L.; Chen, S. W.; Humera, A. (2007). Changes of chemical and nutrient composition of porcine blood during fermentation by Aspergillus oryzae. World J. Microbiol. Biotechnol. 2007, 23 (10), 1393-1399.

(38) Joshi, V. K.; Sandhu, D. K. Preparation and evaluation of an animal feed byproduct produced by solid-state fermentation of apple pomace. Bioresour. Technol. 1996, 56 (2-3), 251-255.

(39) Khan, R. U.; Naz, S.; Dhama, K.; Saminathan, M.; Tiwari, R.; Jeon, G. J.; Laudadio, V.; Tufarelli, V. Modes of action and beneficial applications of chromium in poultry nutrition, production and health: a review. Int. J. Pharmacol. 2014, 10 (7), 357-367.

(40) Van Ryssen, J. B. J. Trace elements in poeltry litter: prevalence and risks. In Trace Elements in Animal Production Systems; Schlegel, P., Durosoy, S., Jongbloed, A. W., Eds.; Wageningen A.P.: Wageningen, The Netherlands, 2008; pp 101-114.

(41) Michalak, Z.; Chojnacka, K.; Glavič, P. The possibilities of the application of feed additives from macroalgae in sustainable mineral animal feeding. Am. J. Appl. Sci. 2009, 6 (8), 1458-1466.

(42) Gaudrén, D.; Quiniou, N. What mineral and vitamin levels to recommend in swine diets? R. Bras. Zootec. 2009, 38, 190-200.

(43) Perry, T. W. Typical composition of feedstuffs for cattle. In Beef Cattle Feeding and Nutrition; Perry, T. W., Cecava, M. J., Eds.; Academic Press: San Diego, CA, USA. 1995; pp 371-380.

(44) Davis, D. A.; Gatlin, D. M. Dietary mineral requeriments of fish and marine crustaceans. Rev. Fish. Sci. 1996, 4, 75-99.

(45) Abdeshahian, P.; Samat, N.; Hamid, A. A.; Yusoff, W. M. W. Solid substrate fermentation for cellulase production using palm kernel cake as a renewable lignocellulosic source in packed-bed bioreactor. Biotechnol. Bioprocess Eng. 2011, 16 (2), 238-244.

(46) Gutarra, M. L.; Cavalcanti, E. D.; Castillo, L. R.; Freire, D. M.; Sant'Anna, G. L. Lipase production by solid-state fermentation: cultivation conditions and operation of tray and packed-bed bioreactors. Appl. Biochem. Biotechnol. 2005, 121-124, 105-116. 